\title{
GEOLOGIC MAP OF THE NORTHWESTERN PART OF THE UNCOMPAHGRE UPLIFT, GRAND COUNTY, UTAH, AND MESA COUNTY, COLORADO, WITH EMPHASIS ON PROTEROZOIC ROCKS
}

\author{
By J.E. Case
}

\begin{abstract}
INTRODUCTION
Precambrian rocks are exposed in erosional windows in the Uncompahgre uplift of Colorado and Utah and along major fault blocks along the flanks of the uplift, which partly coincides with the geomorphic Uncompahgre Plateau. The Uncompahgre uplift is a northwest-trending Laramide structure bordered on its southwestern and northeastern flanks by faulted monoclines (Williams, 1964; Cashion, 1973). It plunges northwestward beneath the Uinta basin. It is a rejuvenated segment of the late Paleozoic and early Mesozoic Uncompahgre highland, an element of the ancestral Rocky Mountains (Dane, 1931, 1935; Holmes, 1956; Tweto, 1980a). Structural relief across the southwestern flank of the uplift is as much as $5,800 \mathrm{~m}$, but structural relief on the base of the Wingate Sandstone of Late Triassic age is only about 1,800 to $2,400 \mathrm{~m}$. Most of the difference in structural relief is due to Late Pennsylvanian and Permian deformation. This early uplift is documented by thick redbed sequences of Permian age (Cutler Formation) and Triassic age (Moenkopi Formation) that are preserved on the flanks of the uplift and in the Paradox basin but are absent on the crest of the uplift where the Upper Triassic Chinle Formation rests on Proterozoic rocks. Southeast along the uplift, progressively younger Mesozoic strata rest unconformably on the Proterozoic surface (Williams, 1964; Hansen, 1981).

In the Paradox basin, many regional aeromagnetic and gravity anomalies arise from features within the basement rather than from the Phanerozoic rock sequence (Case, 1966; Case and Joesting, 1972). After this fact was recognized, geology, gravity, and aeromagnetic data were studied jointly for the northwestern Uncompahgre uplift during the early 1960's. Results of the geophysical surveys were reported by Case (1966) and Case and Joesting (1972), but only a brief outline of the Proterozoic geology was presented in those reports. This report is intended as a somewhat more comprehensive description of the Proterozoic rocks and their deformational style and history. The 1:24,000-scale geologic map combines the results of regional reconnaissance mapping and detailed mapping at a scale of 1:12,000. This report emphasizes the areal geology of the Proterozoic rocks rather than their petrography and chemical composition. These rocks merit far more petrographic, chemical, and isotopic work than has been done for this investigation.

Most of the geology was mapped during 1961-1966, but brief visits were made to the area in 1970,1982, and 1988. This report was completed as part of the investigations of the mineral resource potential of the Black Ridge Canyons, Colorado and Utah, and Westwater Canyon, Utah, Wilderness Study Areas (Dickerson and others, 1988).
\end{abstract}

Precambrian rocks are exposed in the mountain ranges of central and western Colorado and northeastern Utah but are buried beneath most of the Colorado Plateau region (fig. 1). The regional geologic setting of these rocks is well displayed on geologic maps of Utah (Hintze, 1980) and various geologic maps of Colorado (Tweto, 1979, 1980b, 1987). Precambrian rocks are well exposed in the Black Canyon area of the Gunnison uplift (Hansen 1971) and in the Needle Mountains segment of the San Juan Mountains (Barker, 1969).

The most northwesterly exposures of Proterozoic rocks are near the Utah-Colorado border, where the uplift plunges northwestward beneath the Uinta basin. Other nearest Proterozoic exposures are in the Grand Canyon region $400 \mathrm{~km}$ to the southwest; in the Uinta uplift to the north and northwest; in the White River uplift to the northeast; and in the Needle Mountains to the southeast. Some drill holes on the Colorado Plateau have penetrated Precambrian rocks (summarized by Case and Joesting, 1972). The Proterozoic rocks of the northwestern Uncompahgre uplift were briefly described by Dane (1935), but they were not mapped systematically until 1961 when this study originated. Photogeologic maps of part of the area were prepared by Hackman (1959a,b), but the Proterozoic rocks were not subdivided.

\section{DISTRIBUTION OF PRINCIPAL PROTEROZOIC UNITS}

The most widespread exposures of Proterozoic rocks in the northwestern part of the Uncompahgre uplift are in Unaweep Canyon (fig. 1) where they comprise a wide variety of granitoid rocks and some metamorphic rocks of amphibolite facies. Proterozoic rocks are also widely exposed in Colorado National Monument (Lohman, 1965), in the Black Ridge Canyons Wilderness Study Area (Toth and others, 1983; Dickerson and others, 1988), and in the eastern part of the Westwater Canyon Wilderness Study Area (Dickerson and others, 1988), where they are principally granite, gneiss, and pegmatite. The Proterozoic geology of these areas has not been mapped in detail, although Cater (1955) briefly described rocks in the Gateway quadrangle at the southwestern end of Unaweep Canyon, and several isotopic dates have been reported for granitoid plutons in Unaweep Canyon (Davis, 1954; Shoemaker, 1956; Aldrich and others, 1957, 1958; Hedge and others, 1968; Mose and Bickford, 1969; Cudzilo, 1970, 1971; Bickford and Cudzilo, 1975). Tweto (1987) provided a brief summary of rocks exposed in the region as part of his comprehensive review of the Precambrian rocks of Colorado.

Proterozoic rocks described in this report can be divided into two groups-a structurally lower sequence of Early Proterozoic gneiss and younger intrusive rocks. The Early Proterozoic metamorphic rocks include feldspathic gneiss (Xfg), amphibole 


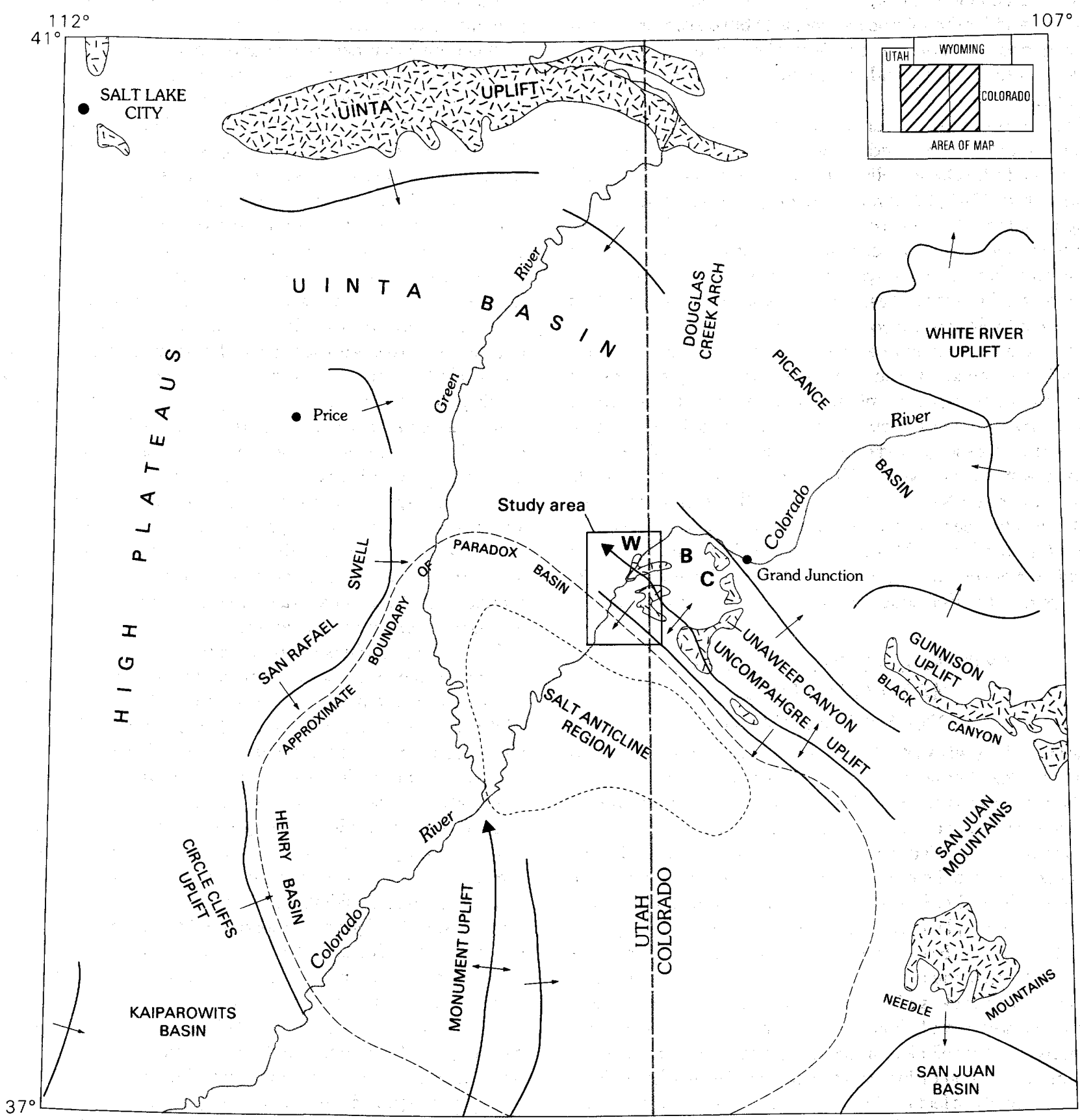

60
-60 KLOMETERS

\section{EXPLANATION}

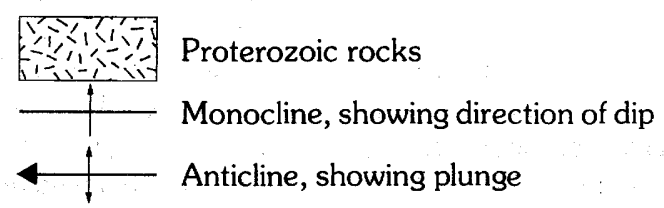

Figure 1. Part of Colorado Plateau region of Utah and Colorado, showing location of study area. C. Colorado National Monument; B, Black Ridge Canyons Wilderness Study Area; W, Westwater Canyon Wilderness Study Area. 
gneiss and amphibolite (Xa), porphyroblastic microcline gneiss (Xpmg), and biotite-microcline gneiss (Xbm). Also present in this sequence is minor quartzite $(\mathrm{Xq})$. This sequence is exposed in Westwater Canyon and its tributaries and along the Dry Gulch fault zone.

The main units in the younger intrusive rocks are (1) gneissic granodiorite $(\mathrm{Xgg})$ exposed along Coates Creek and the upper part of the Little Dolores River, (2) a pluton of metadiorite and metagabbro ( $\mathrm{YXd}$ ), $3.2 \mathrm{~km}$ in diameter, exposed in the lower canyon of the Little Dolores River and in Marble Canyon, (3) biotite granodiorite ( $\mathrm{Ybg}$ ) exposed in the Ryan Park area, and (4) a batholith of coarse-grained, porphyritic biotite quartz monzonite, the Vernal Mesa(?) (Yv), exposed from Ryan Park northwest to Spring Canyon.

The quartz monzonite and metadiorite intrude the older gneissic sequence. These main units are cut by a variety of pegmatites, aplites, lamprophyres, and metapyroxenite bodies. The quartz monzonite body has several compositional variants, as does the gneissic granodiorite, which is a locally synkinematic phase of a magmatic episode. These rocks have been isotopically dated at about 1.45 to $1.7 \mathrm{Ga}$. Some of the gneiss resembles rocks in other parts of Colorado that are between 1,790 and 1,650 Ma; the Vernal Mesa of the Black Canyon region was dated by Hansen and Peterman (1968) at 1,449 $\pm 40 \mathrm{Ma}$ and is, thus, part of the Berthoud Plutonic Suite of Tweto (1987).

\section{EXPANDED DESCRIPTION OF MAJOR MAP UNITS PROTEROZOIC ROCKS}

Feldspathic gneiss (Xfg)-The lowest unit structurally, and one of the most coherent, is the quartz-feldspar gneiss that is well exposed in Westwater Canyon and its tributaries and is sporadically exposed along the Dry Gulch fault zone. It is well foliated and has a distinctive white color when viewed from a distance. It is also the most compositionally uniform unit of the metamorphic units. The common mineral assemblage is quartz (47-67 percent), plagioclase (8-35 percent; about An29), potassium feldspar (2-15 percent), biotite (1-24 percent), and minor amphibole, muscovite, apatite, sphene, garnet, and opaque minerals. The rock is silicic and sodic and is low in potassium and iron (table 1) and, thus, is keratophyric or trondhjemitic in composition. Amphibolite, amphibole gneiss, and quartz amphibolite are very common in layers that are parallel or subparallel to the foliation of the feldspathic gneiss, but locally they cut across it. The associated amphibolite sequence ( $\mathrm{Xa}$ ) is metavolcanic or metaplutonic. Small, tight folds are not common in the unit, but prominent mineral lineations and open-crenulation folds are pervasive. Boudinage is a common cross-lineation and crossfoliation feature. Pegmatitic and aplitic segregations parallel to foliation planes are abundant.

The feldspathic gneiss is unfavorable for dating by wholerock $\mathrm{Rb}$-Sr methods because it has a very low rubidium content and a relatively high strontium content. This method, however, yielded an age of $1,595 \pm 130 \mathrm{Ma}$ (Hedge and others, 1968; values recalculated to new $\mathrm{Rb}$-Sr decay constant by J.C. Reed, Jr. using a factor of 0.97880 ). Zircons yielded ages older than 1,700 Ma (Leon T. Silver, oral commun., 1987).

Amphibole gneiss and amphibolite $(X a)$-This unit is characterized by fine- to medium-grained amphibole gneiss composed of green amphibole (49-72 percent), quartz (17-34 percent), plagioclase (1-13 percent), and potassium feldspar (1-8 percent) that has much variation in relative proportions. Some of the gneiss contains biotite rather than amphibole, and some contains both amphibole and biotite. Locally, the amphibole gneiss contains garnet. Mineral lineation marked by elongation of mineral grains and aggregates is ubiquitous, and, where small folds are present, long axes of amphibole are parallel to fold axes. Cross-lineations, where they occur, are expressed as open folds, kinks, and boudins. The sequence is cut by pegmatite, by coarse-grained altered metapyroxenite(?), and by coarse-grained amphibolite plugs and dikes. Layers of layered quartzite $(X q)$, generally parallel to adjacent gneiss layers and as much as $3 \mathrm{~m}$ thick, are conspicuous features of the main amphibole gneiss sequence. These quartzites have been recrystallized, and local pegmatitic quartz probably indicates melting and segregation. The quartzites are regarded as metasedimentary; if so, the adjacent amphibole gneiss may originally have been extrusive. The amphibole gneiss sequence grades downward structurally into the feldspathic gneiss sequence. Layers of feldspathic gneiss are common near the lower part of the amphibole gneiss sequence but are rare in the structurally higher part of the sequence. The contact with the structurally higher biotite-microcline gneiss $(\mathrm{Xbm})$ and gneissic granodiorite $(\mathrm{Xgg})$ is generally sharp, and amphibole gneiss is virtually absent above the contact.

This unit probably had a basaltic or andesitic protolith, and the discordance of some amphibolite layers indicates an intrusive origin. Chemical analyses (table 1) indicate that some of the amphibolites are tholeiitic. Thus, the amphibole gneiss and feldspathic gneiss are regarded as a basalt-keratophyre association, probably a sequence of texturally homogeneous flows, sills, and dikes or their pyroclastic associates.

Porphyroblastic microcline gneiss (Xpmg)-A distinctive biotitic augen gneiss forms two large sill-like lenticular bodies in the upper reaches of Westwater Canyon. This unit commonly forms rounded, bouldery outcrops. The rock resembles the Vernal Mesa(?) Quartz Monzonite (Yv) batholith exposed south of the Dry Gulch fault zone in composition and mineralogy, but its strong foliation suggests that it is much older. The gneiss contains potassium feldspar (about 24-34 percent), quartz (29-33 percent), plagioclase (25-33 percent; about An28), biotite (10-12 percent), and minor muscovite. It contains porphyroblasts (or porphyroclasts) of pink potassic feldspar that commonly are $6 \mathrm{~mm}$ to $2.5 \mathrm{~cm}$ long and mostly are euhedral to subhedral, but some are sheared out into "bird's-eye" patterns. The porphyryoblasts appear to be late features, because foliation wraps around crystals in places, but the long axes of the crystals generally are parallel to the regional foliation of the enclosing rocks. However, shearing of some porphyroblasts indicates that they predate at least one deformational episode. The lenticular sills, 60 to $120 \mathrm{~m}$ thick, appear to have been emplaced within or adjacent to the amphibole gneiss (Xa) and near hinges of antiforms, perhaps as dilatant intrusions. They contain aplitic and pegmatitic phases, and an aplite dike cuts the foliation of the main amphibole gneiss unit in the upper part of Westwater Canyon; however this aplite may be unrelated genetically to the porphyroblastic gneiss.

The porphyroblastic gneiss has an age of $1,635 \pm 30 \mathrm{Ma}$ as determined by whole-rock Rb-Sr methods by Hedge and others 
(1968), who regarded the ages as approximating the time of metamorphism rather than the time of emplacement because of probable resetting of the $\mathrm{Rb}-\mathrm{Sr}$ system. On balance, the unit is probably of igneous origin and probably is synkinematic. The feldspar porphyroblasts may be late-stage metasomatic features. Alternatively, they might also be early formed phenocrysts rotated into parallel orientation and sheared by protoclastic flowage during emplacement.

Biotite-microcline gneiss (Xbm)-Highly deformed, thinly layered, locally migmatitic, pinkish biotite-microcline gneiss is widely exposed along Spring Canyon, the upper part of Coates Creek, the upper part of the Little Dolores River, and in the upper part of Westwater Canyon. Compositionally, the unit is highly variable; it commonly includes quartz (30-46 percent), potassium feldspar (9-35 percent), plagioclase (12-21 percent), and biotite (10-29 percent). Amphibole-rich layers are present locally, and sillimanite has formed in parts of the sequence. Individual layers range from $3 \mathrm{~mm}$ to as much as $1 \mathrm{~m}$ in thickness. The general aspect of this unit is much like that of some gneiss of the Front Range and Sawatch Range, in central Colorado, and the Black Canyon area (Hansen, 1971), which are thought to be metasedimentary. The unit is cut by the gneissic granodiorite (Xgg), the Vernal Mesa(?) Quartz Monzonite (Yv), and the Little Dolores River pluton ( $Y X d)$. No isotopic ages have yet been determined.

Gneissic granodiorite ( $\mathrm{Xgg}$ )-A unit of medium- to coarsegrained, gray gneissic granodiorite is widely exposed along Coates Creek and the upper part of the Little Dolores River. The rock varies from massive to well foliated. The rock consists of plagioclase (18-28 percent), quartz (25-36 percent), biotite (13-41 percent), amphibole (1-18 percent), and potassium feldspar (7-29 percent). It intrudes the biotite-microcline gneiss. Clearly defined crosscutting relations are exposed in Spring Canyon, but sill-like, concordant layers of gneissic granodiorite are also interlayered with the biotite-microcline gneiss $(\mathrm{Xbm})$. Foliated phases appear to have been deformed at the same time as the biotite-microcline gneiss. The gneissic granodiorite is intruded by the Vernal Mesa(?) (Yv) in Spring Canyon.

The gneissic granodiorite has a whole-rock $\mathrm{Rb}-\mathrm{Sr}$ age of $1,635 \pm 40 \mathrm{Ma}$ (Hedge and others, 1968). Zircon ages are 1700+ $\mathrm{Ma}$ (Leon T. Silver, oral commun., 1987). The unit is probably a member of the Routt Plutonic Suite of Tweto (1987).

Metadiorite and metagabbro ( $Y X d)-A$ composite pluton of metadiorite, metagabbro, and meta-quartz diorite, about 3.2 $\mathrm{km}$ across, intrudes the biotite-microcline gneiss (Xbm) in the lower canyon of the Little Dolores River and in Marble Canyon. This unit is informally called the Little Dolores River pluton (fig. 2). Beneath its cover of Mesozoic rocks, it has a crudely oval outline indicated by its associated magnetic and gravity highs (Case, 1966). It forms dark-gray, bouldery outcrops. Along the contact zone with the gneiss, which is somewhat brecciated and contains hornfels, numerous gneissic inclusions are surrounded by dioritic or gabbroic selvages. The rock is medium to coarse grained. More silicic phases consist of plagioclase (28-43 percent; about An30), amphibole (17-21 percent), quartz (12-23 percent), and potassium feldspar (6-9 percent). Less silicic phases consist of scant quartz (about 1-2 percent), minor potassium feldspar (about 2 percent), plagioclase (57 percent), amphibole (30-32 percent), and opaque minerals (4-6 percent). Garnet, magnetite, sphene, and apatite are common accessory minerals. Amphibole phenocrysts, pseudomorphous after pyroxene, have been recognized in some thin sections. Small metadiorite bodies, probably apophyses of the main pluton, are exposed in the upper part of Westwater Canyon.

Analyses of metagabbros (table 1) indicate that they are high-aluminum, low-sodium rocks; the proportion of total iron ranges considerably. Samples collected for $\mathrm{Rb}-\mathrm{Sr}$ analysis were unsuitable for dating because of low $\mathrm{Rb}-\mathrm{Sr}$ ratios (Hedge and others, 1968).

Metapyroxenite (YXp)-Altered ultramafic bodies of metapyroxenite and minor metagrabbro are common in Westwater Canyon and vicinity. Most of the bodies are 1 to $15 \mathrm{~m}$ across. Most are partly altered to hematitic and chloritic material; they are composed of medium- to coarse-grained green amphibole, with or without plagioclase. Relict pyroxene cleavage can be recognized in amphibole pseudomorphs in a few samples. Two analyzed samples have low $\mathrm{SiO}_{2}$ and high $\mathrm{MgO}$ content (table 1).

Biotite granodiorite (Ybg) - Gray to pink biotite-bearing grantoid rocks are exposed in two large masses along the Ryan Creek fault-zone scarp in Ryan Park and in a tributary canyon south of Granite Creek. The rocks, true granite to quartz monzonite, contain quartz (11-39 percent), plagioclase (20-52 percent), potassium feldspar (8-24 percent), biotite (3-20 percent), and minor opaque minerals, sphene, and apatite. The granitoid rocks are foliated near contacts in a few places, perhaps due to shearing. Age relations between these rocks and the main quartz monzonite $(\mathrm{Yv})$ were not determined. In Unaweep Canyon, gray to pink granitoid bodies are younger than the Vernal Mesa(?) Quartz Monzonite as determined by crosscutting relations and isotopic ages (Mose and Bickford, 1969).

Vernal Mesa(?) Quartz Monzonite (Yv)-Coarse-grained, porphyritic biotite quartz monzonite and minor granodiorite is the most widespread Proterozoic unit of the southern part of the map area. This distinctive rock is lithologically identical with the Vernal Mesa Quartz Monzonite in the Black Canyon area of the Gunnison uplift (Hansen and Peterman, 1968; Hansen, 1971), which is part of the Berthoud Plutonic Suite of Tweto (1987). It is extensively exposed from Granite Creek and Ryan Park in the southeastern part of the map area to Spring Canyon in the central part. It is especially well exposed along the drainages of Renegade Creek and Cow Creek and along the Ryan Creek fault zone. It is also well exposed in the Gateway quadrangle to the southeast (Cater, 1955). Its total extent within the map area is about $56 \mathrm{~km}^{2}$. If exposures in Unaweep Canyon are included, the body has batholithic dimensions. Magnetic surveys, moreover, indicate its presence under large areas of concealment (Case, 1966). The quartz monzonite intrudes both the gneissic granodiorite $(\mathrm{Xgg})$ and biotitemicrocline gneiss (Xbm) in Spring Canyon; hence, it is one of the youngest Proterozoic units.

Most of the quartz monzonite has white to pink euhedral feldspar phenocrysts as much as $5 \mathrm{~cm}$ in length. The rock consists of plagioclase (32-41 percent; about An32), potassium feldspar (29-33 percent), biotite (13-20 percent), and quartz (8-15 percent). Sphene is an abundant mineral (as much as 3 percent); the rock also contains variable amounts of amphibole, apatite, epidote, and opaque minerals, especially magnetite. Useful modal analyses cannot be obtained from standard thin 
sections because of the large size of the feldspar phenocrysts. The one chemical analysis (table 1) is somewhat atypical for quartz monzonite, being low in silica. Similar rocks in Unaweep Canyon are granodiorite (Mose and Bickford, 1969), so that a fairly wide compositional range for the batholith is indicated.

The rock typically forms large, rounded bouldery outcrops. It is generally massive and nonfoliated, but locally it has a weak foliation, perhaps due to flow or local shearing. Although most of the unit is coarse-grained and porphyritic, local fine- to medium-grained phases are nonporphyritic. A great variety of pegmatite and aplite cuts the quartz monzonite; these rocks are thought to be late phases of the batholithic episode.

Where the quartz monzonite intrudes the gneissic granodiorite and biotite-microcline gneiss in Spring Canyon, the contacts are relatively sharp; in a few places, the contact zone is only a few centimeters wide. Generally, however, the contact zone (Ycz) is wider, reaching as much as $60 \mathrm{~m}$. Within the contact zone, the adjacent gneiss has been injected with numerous dikes and apophyses of quartz monzonite, quartz veinlets, pegmatite, and aplite and is commonly brecciated and hornfelsed. Micaceous minerals in the gneiss tend to increase in grain size near the quartz monzonite. In general, contactmetamorphic effects do not appear to extend more than $50 \mathrm{~m}$ from the batholith.

Whole-rock Rb-Sr ages of 1,449 \pm 40 Ma have been reported for samples of the Vernal Mesa(?) from Unaweep Canyon and the Vernal Mesa from the Black Canyon of the Gunnison uplift (Hedge and others, 1968; Hansen and Peterman, 1968; Hansen, 1971, 1981). Mose and Bickford (1969) reported a whole-rock $\mathrm{Rb}-\mathrm{Sr}$ age of $1,658 \pm 108 \mathrm{Ma}$ for samples from Unaweep Canyon, but subsequent $\mathrm{U}-\mathrm{Pb}$ determinations on zircons indicated an age of about 1,443 $\pm 22 \mathrm{Ma}$ (Bickford and Cudzilo, 1975).

Lamprophyre (YI)-Many dikes and irregular bodies of lamprophyre are found throughout the area. These rocks are rich in amphibole, biotite, and various proportions of feldspar, quartz, and other minor minerals. Some bodies are almost entirely green amphibole; others contain mainly biotite. Lamprophyre is commonly associated with pegmatite or aplite, especially in Spring Canyon and Kings Canyon. The bodies range in thickness from about a few centimeters to $30 \mathrm{~m}$. A body in the drainage of the upper part of Coates Creek is about $600 \mathrm{~m}$ long. Many bodies are weathered to a greater extent than adjacent gneiss, but others stand as resistant ridges. Some bodies are weakly foliated but others are not. From scant petrographic data, the rocks have been metamorphosed to amphibolite facies.

Pegmatite $(Y p)$ and quartz pegmatite $(Y q)-P e g m a t i t e$ bodies consisting of quartz, feldspar, and mica are found throughout the Proterozoic terrane. Proportions of the main minerals are highly variable; individual pegmatite varies in composition from nearly pure quartz, such as that exposed in the cliff face north of Ryan Park, to nearly pure feldspar. Most pegmatite contains biotite or muscovite, and tourmaline is common. Many dikelike bodies have steep contacts with adjacent rocks, but many other bodies are relatively flat and sill-like. Lengths range from about a few centimeters to more than $300 \mathrm{~m}$. Far more pegmatite bodies are present than appear on the geologic map, especially in the quartz monzonite (Yv) terrane in the southern part of the area.
Aplite (Ya)-Aplite dikes and sills in fine- to medium-grained aggregates of quartz, feldspar, and mica are common throughout the area and are especially abundant in the quartz monzonite $(\mathrm{Yv})$. Bodies range in thickness from about a few centimeters to $30 \mathrm{~m}$ or more.

\section{PALEOZOIC AND MESOZOIC STRATA}

The Phanerozoic strata described here were further described by Dane (1935), Cater (1955), Williams (1964), Lohman (1965), Stewart and others (1972), Cashion (1973), O'Sullivan and Pipiringos (1983), Toth and others (1983), and Dickerson and others (1988).

Cutler Formation (Pc) - The Cutler Formation is exposed only in the southeastern part of the map area near Granite Creek and Lost Horse Basin. It is a coarse-grained arkosic conglomerate and sandstone sequence containing minor quantities of red siltstone. Crossbeds, channels, and ripple marks are common. The petrography of the Cutler in the Gateway quadrangle has been described by Cater (1955) and Werner $(1972,1974)$. Gravels and boulders are composed of various granitoid and metamorphic rock types. About $90 \mathrm{~m}$ of the Cutler is exposed along Granite Creek. The unit thickens dramatically to the southeast in the Gateway quadrangle and to the southwest toward the deep part of the Paradox basin, where it may be as much as 3,000 m thick (Elston and others, 1962; Case and Joesting, 1972; White and Jacobson, 1983). The formation has been dated as Early Permian in the Paradox basin (Cater, 1970). No evidence for age was found in this study.

Moenkopi(?) Formation ( $\mathbf{F m}$ )-About $30 \mathrm{~m}$ of purplish-red sandstone and siltstone near Ryan Creek in the southern part of the area has been tentatively assigned to the Moenkopi Formation. The unit is below the typical brick-red to brownishred Chinle Formation, but it lacks the pebble and cobble conglomerate typical of the Cutler Formation. If it is the Moenkopi, it thickens greatly toward the south and southwest (Cater, 1955, 1970). The Moenkopi is regarded as Early and Middle(?) Triassic in age in the region (Stewart and others, 1972).

Chinle Formation (KC) - This unit is a distinctive brick-red to brownish-red fluvial sequence that includes thin-bedded, locally crossbedded and channeled siltstone, mudstone, and sandstone and a few thin lenses of conglomerate. Thickness ranges from about 12 to $25 \mathrm{~m}$, in the northern part of the area, to $36 \mathrm{~m}$ or more in the extreme southern part. The formation is preserved across the northwestern part of the Uncompahgre uplift where it rests on Proterozoic rocks, but in the southern part of the area it rests on the Cutler and Moenkopi(?) Formations. The Chinle has been dated as Triassic elsewhere on the Colorado Plateau (Stewart and others, 1972). Stewart and others (1972) measured and described a section near the head of Westwater Canyon, and Dane (1935) described sections near Big Hole and near the Dry Gulch fault zone.

Wingate Sandstone ( $\mathrm{KW}$ )-This formation is about 90 to 130 $\mathrm{m}$ thick and is the most widely exposed major cliff-forming unit of the area. It is characterized by massive beds and eolian crossbeds, which are commonly buff, cream, or rust. The sandstones are quartzose, feldspathic, and very fine to medium grained. The basal contact with the Chinle Formation is very sharp. Dane (1935) described measured sections at Big Hole 
and near the Dry Gulch fault zone. The Wingate is Late Triassic in age, but no evidence for its age has been found in the map area.

Kayenta Formation ( $\mathbf{k k}$ ) - This formation is a sequence of crossbedded and channeled sandstone, siltstone, and local mudstone that is generally well cemented and forms a protective cap above the Wingate Sandstone. The sandstone is quartzose and feldspathic. The formation is buff, tan, or reddish brown. It appears to be gradational with the Wingate, so the mapped contact is somewhat arbitrary, and the contact is considered approximate everywhere on the geologic map. According to Dane (1935), the formation ranges from 60 to $98 \mathrm{~m}$ in thickness west and southwest of Ryan Creek. The formation is overlain by the Entrada Sandstone, but the contact is not exposed in the mapped area. The Kayenta may be Late Triassic(?) in age, but no evidence for its age has been found in the map area. The formation is widely regarded as fluvial, according to Lohman (1965).

Entrada Sandstone (Je) - This. Middle Jurassic formation is composed of pinkish-cream to buff, quartzose, feldspathic sandstone that has large-scale eolian crossbeds. The sandstone is very fine to coarse grained and locally contains small, rounded, iron oxide-stained quartz and chert granules known informally as "Entrada berries." Exposed thickness is at least 30 $m$ along the Dry Gulch and Little Dolores River fault zones and on Piñon Mesa.

Tidwell(?) Member of Morrison Formation (Jtml and Jtmu)-Maroon, brownish, reddish-brown, thin-bedded limestone, siltstone, mudstone, and sandstone (Jmtl) are present above the Entrada and are about 9 to $11 \mathrm{~m}$ thick where exposed at the western ends of the Dry Gulch and Little Dolores River fault zones. Locally, a thin ( 3 to $4.5 \mathrm{~m}$ ), lenticular, gray, massive, cliff-forming limestone ( $\mathrm{Jmtu}$ ) was deposited above the lower redbeds. In the Grand Junction area to the east, a similar unit was designated the Summerville Formation by Lohman (1965), who regarded the lower part of the unit as lacustrine or lagoonal. The limestone was probably deposited in a playa environment similar to that of the lenticular limestone in the eolian Navajo Sandstone, about $3 \mathrm{~km}$ southwest of the map area. Subsequent regional stratigraphic studies by O'Sullivan and Pipiringos (1983) indicate that these rocks are probably part of the Tidwell Member of the Upper Jurassic Morrison Formation. A measured section of this unit along the Dry Gulch fault zone was made by O'Sullivan and Pipiringos (1983).

Salt Wash Member of Morrison Formation (Jms)-This varicolored unit is exposed only at the western ends of the Dry Gulch and Little Dolores River fault zones. The unit includes alternating layers of cream to buff sandstone, 0.3 to $4.5 \mathrm{~m}$ thick, separated by thin lavender, maroon, green, and gray mudstone and siltstone. Thin conglomerate lenses are common. Crossbedding and channeling are common in the sandstone. The upper part of the Salt Wash Member has been eroded; the exposed thickness is about $30 \mathrm{~m}$. To the east, in the Grand Junction area, the total thickness of the Salt Wash Member is about $100 \mathrm{~m}$ (Lohman, 1965); to the south and southwest, the thickness is about 100 to $110 \mathrm{~m}$ (Cater, 197.0). The Salt Wash is regarded as fluvial and lacustrine (Lohman, 1965).

\section{CENOZOIC DEPOSITS}

Terrace and channel gravels (QTg)-Pebble and cobble gravels cap benches in Westwater Canyon above the present incised canyon and in Big Hole, which is an ancient incised meander of the Colorado River. The gravels contain clasts of (1) volcanic rocks typical of those of Cenzoic age in the San Juan Mountains and elsewhere in central Colorado; (2) Precambrian metamorphic and igneous rocks, including abundant quartz; and (3) sandstone, limestone, and chert from Phanerozoic sources. Thicknesses are 3 to $8 \mathrm{~m}$, or more. Other gravel deposits are found in the broad valley of the upper part of Coates Creek, which may be an abandoned tributary channel of the ancestral Colorado-Gunnison River systems (Sinnock, 1981; Lohman, 1965, 1981).

Landslide deposits (Q/s)-Deposits of angular boulders and rubble at the base of and across steep cliffs.

Fan deposits (Of)-Boulder, pebble, and sand deposits in alluvial fans and cones in Ryan Park.

Colluvium (Qc)-Earthflow, mudflow, landslide, and talus deposits.

Alluvium (Qal) - Chiefly silt, sand, and gravel deposits in flood plains and on low terraces.

Surficial deposits, undivided (Qs) - Surficial deposits include all Quaternary depositional types described above.

\section{PROTEROZOIC STRUCTURE FOLDS}

Metamorphic rocks of the northwestern part of the Uncompahgre uplift are highly deformed. At least two major episodes of folding can be recognized, and a third premetamorphic episode is likely. The earliest recognizable episode was characterized by development of metamorphic foliation and lineation, and by folds that have axial surfaces that trend north, northwest, and northeast. During a later episode of folding, the early formed folds were refolded about axial surfaces that trend at a high angle to the early axial surfaces. Folds of the second set are broad, open folds, and warps. Lineations produced by the second deformation include axes of small folds, kink bands, and elongate boudins. The style of folding was greatly influenced by the relative ductility in each of the major rock units. The feldspathic gneiss (Xfg), amphibole gneiss (Xa), and porphyroblastic microcline gneiss (Xpmg) are more competent than the thinly layered biotite-microcline gneiss (Xbm). The more competent rocks form broad, relatively open folds in contrast with the isoclinal and disharmonic folds that characterize the biotitemicrocline gneiss. Some of the known and inferred major folds are shown schematically (fig. 2; cross sections $A-A^{\prime}, B-B^{\prime}$, and $C-C^{\prime}$ ) where the major rock units have been extrapolated beneath the cover of Phanerozoic strata.

A major doubly plunging fold, termed the Westwater Canyon antiform, which trends about north in the lower part of Westwater Canyon and Star Canyon, is shown on cross sections $A-A^{\prime}$ and $B-B^{\prime}$. The fold is defined chiefly by foliation in the feldspathic gneiss, but locally the thick layer of amphibole gneiss on the eastern limb also aids in recognition of the fold. In Star Canyon, foliation trends from about north to N. $40^{\circ} \mathrm{W}$. Dips are toward the east and northeast, ranging from $15^{\circ}$ to $60^{\circ}$. Dips are steeper in the exposures of amphibole gneiss in tributary canyons of Star Canyon. The western limb of the fold is exposed in Westwater Canyon, south of Big Hole, where foliations trend from north through N. $35^{\circ} \mathrm{E}$. 
The northern nose of the Westwater Canyon antiform is exposed in Westwater Canyon, east and north of Big Hole, where foliations swing smoothly around from northwest strikes on the eastern limb, through east strikes at the nose, to northeast strikes on the western limb (fig. 2; cross section $\left.A-A^{\prime}\right)$. Stereograms of various structural elements suggest that the axial surface is nearly vertical.

A pervasive lineation (L1) is expressed in the feldspathic gneiss by mineral elongation, especially of amphibole and biotite, by the axes of small folds, and by rods, mullions, and "pencil" gneiss. A plot of these lineations, measured south of the northern nose, shows a very tight cluster about a north trend and a plunge of $30^{\circ} \mathrm{N}$ in a near-vertical plane. Thus, for the area immediately north of the younger east-west crossfold, termed the Star Canyon-Marble Canyon antiform (fig. 2; cross section $A-A$ ), northerly lineations dominate. Farther northeast, however, the trend of the axis and axial surface swings northeastward, as shown by the orientation of the hinge axis in the amphibole gneiss and adjacent rocks just south of the junction of the Little Dolores and Colorado Rivers. At that point, the lineations plunge as steeply as $70^{\circ}$.

A second prominent lineation (L2) in the feldspathic gneiss is expressed locally by warping, kinking, pegmatite-filled gashes, or by open folds that trend from east to northeast. Wherever observed, this second lineation is the locus of deformation of the earlier north-south lineation. The L2 lineation is parallel to the axes of mesoscopic folds, as discussed below.

South of an axis of major crossfolding, the Star CanyonMarble Canyon antiform (fig. 2; cross sections $A-A^{\prime}, C-C^{\prime}$ ), lineations (L1) trend south and plunge as steeply as $20^{\circ}$, both in the southern parts of Westwater and Star Canyons. The transition zone from north-plunging to south-plunging lineations is mapped in both canyons; this zone, which trends approximately east, is the axial region of the crossfold, but its details are covered by the Triassic strata. Orientations of L2 lineations aid in defining the crossfold.

The southern limb of this major east-west crossfold is exposed along the Dry Gulch fault zone, (fig. 2; cross sections $\left.A-A^{\prime}, C-C^{\prime}\right)$. Broad, open, south-plunging antiforms and synforms have been mapped (fig. 2), but whether or not these folds are early, late, or rejuvenated structures has not been determined; rejuvenation is suspected. The westernmost antiform (fig. 2) is believed to be a southern nose of the Westwater Canyon antiform. A major open synform is expressed by foliation trends near the head of Star Canyon and along the Dry Gulch fault zone. The synform and the antiform near benchmark Coach (geologic map, sec. 30, T. 21 S., R. 26E.) are open south-plunging folds. On each of these folds, the rocks have a dominant south-plunging lineation (L1) expressed by mineral elongation, axes of small folds, and rodding. These L1 lineations warp around a younger lineation (L2) which trends roughly east. Axes of these folds plunge about $50^{\circ}$ to $60^{\circ} \mathrm{S}$, and their axial surfaces trend approximately south and are nearly vertical.

If the amphibole gneiss, feldspathic gneiss, and biotitemicrocline gneiss continue as discrete units beneath cover from the Dry Gulch fault zone into Star Canyon, then the two major sets of folds are defined (fig. 2). Although the projections of rock units beneath cover are tenuous, the emplacement of the Little Dolores River pluton appears to have pushed aside and deformed the Star Canyon-Marble Canyon antiform. Folds in the upper part of Westwater Canyon, however, appear to plunge into the pluton. This significant structural problem can be resolved only by detailed structural mapping and analysis.

In the central part of Westwater Canyon, the main north to northeast-trending Westwater Canyon antiform converges abruptly with a nearly isoclinal synform, termed the Little Dolores River synform, whose axis and axial surface trend about $\mathrm{N} .60^{\circ} \mathrm{E}$. and whose axis plunges steeply northeast. The synform is defined primarily by the pattern of the contacts between the amphibole gneiss and adjacent units and by foliation trends. The antiformal nose just south of the Little Dolores River is the warped northern nose of the main Westwater Canyon antiform.

North of Little Hole, a broad, steeply plunging antiform is defined by the rock units and foliation trends exposed west of Snyder Mesa. Because the general easterward plunge is $70^{\circ}$ to vertical, the trace of an axial surface is poorly defined. Lineations trend southeast to south, which is why a southeastward trend for the Snyder Mesa antiform is shown (fig. 2). Alternatively, more eastward trends are permitted by the field data.

Still farther north, near the head of Westwater Canyon, a lenticular layer of amphibole gneiss within the biotite-microcline gneiss sequence could be in the northeastern limb of a northwest-trending synformal fold, or it could be merely a lens.

Along the upper course of the Little Dolores River, in Kings Canyon, and in the canyon northeast of Fish Park, foliations in the biotite-microcline gneiss trend generally northwest, north, and east. Northeastward trends are restricted to the upper part of Kings Canyon. Steep southward plunges of lineations dominate, but northward plunges are found also, especially where two lineations are present. Multiple folding is evident in many places. In the Coates Creek area, in the eastern part of the map area near the Dry Gulch fault zone, foliations of the biotite-microcline gneiss and gneissic granodiorite have northeast, north, and northwest trends indicating broad megascopic folds. Lineations generally plunge steeply in southward directions. From patterns of contacts between the two rock units, axial surfaces of antiforms and synforms apparently have dominant north to northeast trends and are nearly vertical.

I speculate that the original sedimentary sequence represented by the biotite-microcline gneiss was flyschlike, on the basis of the rhythmic alternation of pelitic and arenaceous layers, and probably was deformed before the first metamorphic deformation, perhaps as a convergent zone such as in an accretionary prism.

\section{SUMMARY OF PROTEROZOIC EVENTS}

Unless the entire assemblage of metamorphic rocks has been overturned, the following general sequence of Proterozoic events can be interpreted:

1. The earliest recognizable event was the extrusion of keratophyric ignimbrite sheets or the intrusion of shallow(?) sills on or into a basement of unknown age and composition. This silicic activity was accompanied by intrusive (sills) and possible extrusive tholeiitic magmatism to form the protolith of the feldspathic gneiss $(\mathrm{Xfg})$. These events probably predate 1,700 $\mathrm{Ma}$ (U-Pb ages from zircons are older than 1,700 Ma according to Leon T. Silver, oral commun., 1987). 
2. Intrusion and extrusion of tholeitic magma formed the protolith of the amphibole gneiss and amphibolite $(\mathrm{Xa})$. Thin quartzite beds $(\mathrm{Xg})$ that are conformably interlayered with the mafic material indicate episodes of subaqueous or subaerial deposition during the period of volcanism.

3. The magmatic activity was followed by deposition of an enormously thick sequence of thin-bedded clastic sedimentary rocks, mainly silicic and feldspathic, which were probably mudstone, siltstone, and sandstone and were perhaps flysch deposits. These rocks were the protoliths of the biotitemicrocline gneiss $(\mathrm{Xbm})$. The rocks were probably folded before metamorphism, but no evidence exists from the present investigation.

4. Sills of quartz monzonite were next intruded within the tholeiitic pile and along the contact between the mafic rocks and the sedimentary rocks. These intrusions were the protolith of the porphyroblastic microcline gneiss (Xpmg).

5. Emplacement of pyroxenite and lamprophyre dikes and plugs in Westwater Canyon occurred prior to some phase of regional metamorphism, but it is undated.

6. All the older rocks were subjected to regional metamorphism to amphibolite facies, locally to sillimanite subfacies. Rb-Sr ages of about 1,595 $\pm 30 \mathrm{Ma}$ to $1,635 \pm 40 \mathrm{Ma}$ (Hedge and others, 1968) may represent the time of metamorphism. Major folding about axes trending north, northwest, and northeast accompanied or shortly followed metamorphism; some axes plunged steeply. Folding was about near-vertical axial surfaces; little evidence for large-scale recumbent folding has been observed. These relations suggest folding in a strike-slip stress regime.

At about the same time $(1,635 \pm 30 \mathrm{Ma})$, granodiorite $(\mathrm{Xgg})$ synkinematically intruded the older layered sequence. Some of the granodiorite is without foliation, but much is foliated parallel to contacts and layering of the adjacent biotite-microcline gneiss and amphibole gneiss. The intrusion of the granodiorite may have caused much of the deformation and provided heat for the episode of regional metamorphism.

7. An episode of crossfolding after formation of the primary metamorphic mineral lineation was, perhaps, a culmination of earlier metamorphic-deformational events. This episode possibly accompanied emplacement of the Little Dolores River pluton ( $\mathrm{YXd}$ ). The metadiorite and metagabbro pluton was emplaced and metamorphosed (retrograde?) to amphibolite facies without acquiring significant foliation.

For the almost 200 m.y. that followed event 7 , there is no preserved rock record in the northwestern part of the Uncompahgre uplift.

8. The Vernal Mesa(?) Quartz Monzonite (Yv) was emplaced at about 1,443 $22 \mathrm{Ma}$ (Bickford and Cudzilo, 1975). It does not have a detectably wide $(>.4 \mathrm{~km})$ metamorphic aureole. The batholith is generally without foliation. Pegmatites ( $Y p, Y q)$, aplites (Ya), and lamprophyres (YI) were emplaced after the Vernal Mesa(?) batholith.

9. Major Proterozoic shearing along the Dry Gulch fault zone and possibly along the Little Dolores River fault zone followed event 7 (development of crossfolds).

\section{PHANEROZOIC STRUCTURE}

The northwestern part of the Uncompahgre uplift was deformed in two tectonic episodes in Phanerozoic time-first in an episode of late Paleozoic to early Mesozoic uplift of the ancestral Uncompahgre highland and second in an episode of post-Late Cretaceous uplift in the position of the present-day Uncompahgre Plateau (Dane, 1935; Holmes, 1956). Vertical tectonics may have dominated the younger deformation, but the relative significance of vertical versus horizontal compressional events in the late Paleozoic is still problematic. Evidence for high-angle thrusting and relative horizontal shortening along the southwestern flank has been presented by White and Jacobson (1983), Gries (1983), and others.

The Laramide deformation of the northwestern Uncompahgre uplift is characterized by faulted monoclines and homoclines along the northeastern and southwestern flanks and across the northwest-plunging nose of the uplift. Dips of sedimentary strata are steep only in complex tilted blocks and slices in the major fault zones.

The regional structure has been shown by structure contour maps: (1) on the top of the Proterozoic surface (Case, 1966), (2) on the base of the Upper Triassic Wingate Sandstone (Dane, 1935; Heyman, 1983), and (3) on the base of the Upper Cretaceous Dakota Sandstone (Williams, 1964; Cashion, 1973). The difference in structural relief between Proterozoic and Triassic rocks across the southwestern Uncompahgre front is dramatic. Structural relief on Triassic reference horizons (for example, the top of the Chinle Formation or the base of the Wingate Sandstone) from the Paradox basin southwest of the uplift to the crest of the uplift is about $1,800 \mathrm{~m}$, but structural relief of the Proterozoic surface from the basin to the crest of the uplift has been estimated to be about 5,500 to $6,000 \mathrm{~m}$, or more (Dane, 1935; Elston and others, 1962; Case and Joesting, 1972; White and Jacobson, 1983; Frahme and Vaughn, 1983).

Three main fault systems dominate in the mapped area-the Little Dolores River, Dry Gulch, and Ryan Creek fault zones which trend west to northwest. A subsidiary set of faults trends northeast as well. A Proterozoic ancestry for the Dry Gulch fault zone and probably for the Little Dolores River fault zone is documented below. Late Paleozoic and (or) early Mesozoic activity can be demonstrated for the Ryan Creek fault zone.

In the north, the Little Dolores River fault zone trends northwest, and the northeast side is down. Within the map area, the maximum vertical displacement is about $215 \mathrm{~m}$, near Snyder Mesa where the Kayenta Formation and Entrada Sandstone are faulted against Proterozoic rocks. Farther northwest, the fault displacement gradually decreases, and the fault zone passes into the northeastern flank of Sieber nose, about $2 \mathrm{~km}$ northwest of the map area (Case, 1966; Cashion, 1973). Displacement dies out southeastward near Kings Canyon. Hints that this fault zone may be a rejuvenated Proterozoic fault zone include parallelism of foliations of metamorphic rocks near the head of Westwater Canyon (fig. 2) and the presence of numerous aplitic veinlets, brecciation, and possible mylonitization.

The Dry Gulch fault zone is well exposed in the central part of the area. The zone trends about east but has local variations. The south side is down, and maximum displacement is about $215 \mathrm{~m}$. Where the fault surface is exposed, the dip is $55^{\circ}$ to $60^{\circ}$ $\mathrm{S}$. Slickensides plunge south. Displacement decreases eastward to zero on a single main trace in Spring Canyon. The fault splits into many complex splays at the western end near the Colorado River, and displacement diminishes rapidly west of the river (Williams, 1964). This fault zone, as well as the Ryan Creek fault 
zone to the south, passes into the Cisco anticline about $7 \mathrm{~km}$ northwest of the map area. Much evidence indicates that the Dry Gulch fault zone is a rejuvenated Proterozoic feature. Confined to the Proterozoic rocks, but parallel to the simple single trace of the Laramide fault, is a zone of brecciation 5 to $100 \mathrm{~m}$ wide containing angular fragments of gneiss cemented together by aplitic veinlets. Also within the Proterozoic rocks, but close to the trace of the Laramide fault, are small shears, apparent zones of mylonitization, and possible pseudotachylyte (fig. 2).

The complex southern fault system, the Ryan Creek fault zone, trends west to northwest (Dane, 1935). Displacement on individual strands is either upthrown or downthrown on the southwest, depending on locality, but the aggregate displacement on the whole system is downthrown to the southwest (cross section $D-D^{\prime}$ ). A large asymmetric graben in the fault zone at Ryan Park narrows to the northwest. The system ultimately passes into the Cisco anticline to the northwest (Case, 1966). This system provides evidence for growth of the southwestern Uncompahgre front during the late Paleozoic and early Mesozoic. For example, in Lost Horse Basin and Granite Creek, the Lower Permian Cutler Formation is preserved above Proterozoic granitic rocks, but less than a mile northeast, across another major strand of the Ryan Creek fault zone, the Upper Triassic Chinle Formation rests on granitic rocks. The Cutler and Moenkopi Formations, if ever deposited there, were subsequently eroded along paleoscarps of the fault zone. Similar relations in the Gateway quadrangle to the southeast have been described by Cater (1955). A subsidiary northwest-trending fault zone, the Renegade fault zone, is located between the Dry Gulch and Ryan Creek fault zones.

Many northeast-trending Laramide faults have been mapped in the area, especially in the vicinity of Piñon Mesa. Most of them are high angle. Faults in the Ryan Park area are down on the northwest, but faults near the head of Spring Canyon are down on the southeast. Displacements range from 15 to $60 \mathrm{~m}$.

\section{COMMENTS ON GEOMORPHOLOGY}

Lohman $(1965,1981)$ and Sinnock (1981) have described the late Tertiary to Holocene history of the ancestral ColoradoGunnison River system from its ancient course through Unaweep Canyon to its diversion into its present course through Ruby Canyon, about $10 \mathrm{~km}$ northeast of the map area, and Westwater Canyon. Though not mentioned by Lohman (1965, 1981), the river or a large tributary also probably occupied what are now the broad valleys of the Little Dolores River and the upper part of Coates Creek (Sinnock, 1981). Terrace gravels along the upper part of Coates Creek, which rest on eroded Wingate Sandstone, contain angular pebbles and cobbles of amphibolite, gneiss, and quartz that indicate transport and deposition by a stream that had considerably greater competency than the present-day Coates Creek. Lohman $(1965,1981)$ and Sinnock (1981) have described the process as homoclinal shifting of the river along the northeastern flank of the rising Uncompahgre uplift during the late Tertiary and Holocene.

Big Hole, near Westwater Canyon, is an incised meander of a lower, somewhat younger level of the Colorado after the river had shifted its course off the crest of the uplift. Channel and terrace gravels at Big Hole contain abundant volcanic pebbles that are typical of Tertiary volcanic rocks of the San Juan Mountains and elsewhere in central Colorado, as well as pebbles of various Proterozoic rocks and Phanerozoic sedimentary rocks.

Once the river had eroded down to the Proterozoic rocks, probably in the Pleistocene, the course of the river became influenced by the orientation of foliations and lithologic contrasts in the crystalline rocks. For example, the broad eastward bend of the river near Snyder Mesa coincides closely with foliation trends around the plunging nose of the Snyder Mesa antiform; the westward bend near the junction with the Little Dolores River mimics the trends in the Little Dolores River synform; and the eastward bend to the south coincides with the northplunging nose of the Westwater Canyon antiform. Where the river encounters the lithologically homogeneous feldspathic gneiss $(\mathrm{Xfg})$ in the lower part of Westwater Canyon, the structural trends have little influence over the course of the river.

\section{ACKNOWLEDGMENTS}

I wish to especially acknowledge the many stimulating and helpful discussions in the field and office with the late Ogden Tweto. Other beneficial discussions in the field or office were provided by M.R. Bickford, R.P. Dickerson, W.R. Hansen, C.E. Hedge, the late H.R. Joesting, D.G. Mose, J.E. Obradovich, Z.E. Peterman, J.C. Reed, L.T. Silver, W.G. Werner, and P.L. Williams. C.E. Long provided able field assistance for one season. Some modal analyses were made by W.G. Werner. All the local ranchers were most helpful thoughout the study, and I wish to especially thank Mr. and Mrs. George Van Loan and family for many courtesies.

\section{REFERENCES CITED}

Aldrich, L.T., Wetherill, G.W., and Davis, G.L., 1957, Occurrence of 1350 million-year-old rocks in western United States: Geological Society of America Bulletin, v. 68, no. 5, p. 655-656.

Aldrich, L.T., Wetherill, G.W., Davis, G.L., and Tilton, G.R., 1958, Radioactive ages of micas from granitic rocks by $\mathrm{Rb}-\mathrm{Sr}$ and K-Ar methods: American Geophysical Union, Transactions, v. 39, no. 6, p. 1124-1134.

Barker, Fred, 1969, Precambrian geology of the Needle Mountains, southwestern Colorado, in Shorter Contributions to General Geology: U.S. Geological Survey Professional Paper 644-A, p. A1-A33.

Bickford, M.E., and Cudzilo, T.F., 1975, U-Pb age of zircon from Vernal Mesa-type quartz monzonite, Unaweep Canyon, west-central Colorado: Geological Society of America Bulletin, v. 86, no. 10, p. 1432-1434.

Case, J.E., 1966, Geophysical investigations over Precambrian rocks, northwestern Uncompahgre Plateau, Utah and Colorado: American Association of Petroleum Geologists Bulletin, v. 50, no. 7, p. 1423-1443.

Case, J.E., and Joesting, H.R., 1972, Regional geophysical investigations in the central Colorado Plateau: U.S. Geological Survey Professional Paper 736, $31 \mathrm{p}$. 
Cashion, W.B., 1973, Geologic and structure map of the Grand Junction quadrangle, Colorado and Utah: U.S. Geological Survey Miscellaneous Geologic Investigations Map I-736, scale 1:250,000.

Cater, F.W., Jr., 1955, Geology of the Gateway quadrangle, Colorado: U.S. Geological Survey Geologic Quadrangle Map GQ-55, scale 1:24,000.

1970 [1971], Geology of the salt anticline region in southwestern Colorado with a section on Stratigraphy, by F.W. Cater and L.C. Craig: U.S. Geological Survey Professional Paper 637, 80 p.

Cudzilo, T.F., 1970, Reconnaissance geochronology of Precambrian rocks in the central Uncompahgre Plateau, westcentral Colorado: Lawrence, University of Kansas, M.S. thesis, $40 \mathrm{p}$.

1971, Regional aspects of radiometric ages of Precambrian rocks in the central Uncompahgre Plateau, westcentral Colorado [abs.]: Geological Society of America Abstracts with Programs, v. 3, no. 3, p. 235.

Dane, C.H., 1931, Uncompahgre Plateau and related structural features [abs.]: Washington Academy of Sciences Journal, v. 21 , no. 2 , p. 28.

1935, Geology of the Salt Valley anticline and adjacent areas, Grand County, Utah: U.S. Geological Survey Bulletin 863, $184 \mathrm{p}$.

Davis, G.L., 1954, Age of rocks, in Annual report of the Director of the Geophysical Laboratory: Carnegie Institution of Washington Yearbook 53, p. 104-106.

Dickerson, R.P., Case, J.E., Barton, H.N., and Chatman, M.L., 1988, Mineral resources of the Black Ridge Canyons Wilderness Study Area, Mesa County, Colorado, and Grand County, Utah, and Westwater Canyon Wilderness Study Area, Grand County, Utah: U.S. Geological Survey Bulletin $1736-\mathrm{C}, 24 \mathrm{p}$.

Elston, D.P., Shoemaker, E.M., and Landis, E.R., 1962, Uncompahgre front and salt anticline region of Paradox basin, Colorado and Utah: American Association of Petroleum Geologists Bulletin, v. 46, no. 10, p. 1857-1878.

Frahme, C.W., and Vaughn, E.B., 1983, Paleozoic geology and seismic stratigraphy of the northern Uncompahgre front, Grand County, Utah, in Lowell, J.D., ed., Rocky Mountain foreland basins and uplifts: Rocky Mountain Association of Geologists Annual Field Conference, October, 1983, Guidebook, p. 201-211.

Gries, Robbie, 1983, Oil and gas prospecting beneath Precambrian of foreland thrust plates in Rocky Mountains: American Association of Petroleum Geologists Bulletin, v. 67 , no. 1, p. 1-28.

Hackman, R.J., 1959a, Photogeologic map of the Coach Creek SE quadrangle, Grand County, Utah, and Mesa County, Colorado: U.S. Geological Survey Miscellaneous Geologic Investigations Map I-278, scale 1:24,000.

1959b, Photogeologic map of the Coach Creek NE quadrangle, Grand County, Utah, and Mesa County, Colorado: U.S. Geological Survey Miscellaneous Geologic Investigations Map I-279, scale 1:24,000.

Hansen, W.R., 1971, Geologic map of the Black Canyon of the Gunnison River and vicinity, western Colorado: U.S. Geological Survey Miscellaneous Geologic Investigations Map I-584, scale $1: 31,680,2$ sheets.
1981, Geologic and physiographic highlights of the Black Canyon of the Gunnison River and vicinity, Colorado, in Epis, R.C., and Callender, J.F., eds., Western Slope Colorado: New Mexico Geological Society Annual Field Conference, 32nd, October 8-10, 1981, Guidebook, p. 145-154.

Hansen, W.R., and Peterman, Z.E., 1968, Basement-rock geochronology of the Black Canyon of the Gunnison, Colorado: U.S. Geological Survey Professional Paper 600-C, p. C80-C90.

Hedge, C.E., Peterman, Z.E., Case, J.E., and Obradovich, J.E., 1968, Precambrian geochronology of the northwestern Uncompahgre Plateau, Utah and Colorado: U.S. Geological Survey Professional Paper 600-C, p. C91-C96.

Heyman, O.G., 1983, Distribution and structural geometry of folds along the northwestern Uncompahgre uplift, western Colorado and eastern Utah, in Averett, W.R., ed., Northern Paradox basin-Uncompahgre uplift: Grand Junction Geological Society Annual Field Trip, October l-2, 1983, Guidebook, p. 45-62.

Hintze, L.F., compiler, 1980, Geologic map of Utah: Utah Geological and Mineral Survey, scale 1:500,000, 2 sheets.

Holmes, C.N., 1956, Tectonic history of the ancestral Uncompahgre Range in Colorado, in Geology and economic deposits of east central Utah: Intermountain Association of Petroleum Geologists Annual Field Conference, 7th, Guidebook, p. 190-194.

Lohman, S.W., 1965, Geology and artesian water supply, Grand Junction area, Colorado: U.S. Geological Survey Professional Paper 451, 149 p. 1981, Ancient drainage changes in and south of Unaweep Canyon, southwestern Colorado, in Epis, R.C., and Callender, J.F., eds., Western Slope Colorado: New Mexico Geological Society Annual Field Conference, 32nd, October 8-10, 1981, Guidebook, p. 137-143.

Mose, D.G., and Bickford, M.E., 1969, Precambrian geochronology in the Unaweep Canyon, west-central Colorado: Journal of Geophysical Research, v. 74, no. 6, p. 1677-1687.

O'Sullivan, R.B., and Pipiringos, G.N., 1983, Stratigraphic sections of Middle Jurassic Entrada Sandstone and related rocks from Dewey Bridge, Utah to Bridgeport, Colorado: U.S. Geological Survey Oil and Gas Investigations Chart OC-122.

Shoemaker, E.M., 1956, Precambrian rocks of the northcentral Colorado Plateau, in Geology and economic deposits of east central Utah: Intermountain Association of Petroleum Geologists Annual Field Conference, 7th, Guidebook, p. 54-57.

Sinnock, Scott, 1981, Pleistocene drainage changes in Uncompahgre Plateau-Grand Valley region of western Colorado, including formation and abandonment of Unaweep Canyon: a hypothesis, in Epis, R.C., and Callender, J.F., eds., Western Slope Colorado: New Mexico Geological Society Annual Field Conference, 32nd, October 8-10, 1981, Guidebook, p. 127-136.

Stewart, J.H., Poole, F.G., and Wilson, R.F., 1972, Stratigraphy and origin of the Chinle Formation and related Upper Triassic strata in the Colorado Plateau region with a section on Sedimentary petrography, by R.A. Cadigan, and a section on Conglomerate studies, by William Thordarson, 
H.F. Albee, and J.H. Stewart: U.S. Geological Survey Professional Paper 690, $336 \mathrm{p}$.

Toth, M.I., Stoneman, R.J., Patterson, C.G., and Jackson, L.L., 1983, Geology and mineral resource potential of the Black Ridge Canyon Wilderness Study Area, Mesa County, Colorado (GEM Phase 2): U.S. Geological Survey OpenFile Report 83-794, $30 \mathrm{p}$.

Tweto, Ogden, compiler, 1979, Geologic map of Colorado:

U.S. Geological Survey, scale 1:500,000.

1980a, Tectonic history of Colorado, in Kent, H.S., and Porter, K.W., eds., Colorado geology: Denver, Rocky Mountain Association of Geologists, Guidebook, p. 5-9. 1980b, Precambrian geology of Colorado, in Kent, H.S., and Porter, K.W., eds., Colorado geology: Denver, Rocky Mountain Association of Geologists, Guidebook, p. 37-46.

1987, Rock units of the Precambrian basement in Colorado: U.S. Geological Survey Professional Paper 1321-A, $54 \mathrm{p}$.
Werner, W.G., 1972, Sedimentology of the Cutler Formation (Pennsylvanian-Permian) near Gateway, Colorado, and Fisher Towers, Utah: Columbia, University of Missouri, M.S. thesis, $96 \mathrm{p}$.

1974, Petrology of the Cutler Formation (Pennsylvanian-Permian) near Gateway, Colorado, and Fisher Towers, Utah: Journal of Sedimentary Petrology, v. 44, no. 2, p. 292-298.

White, M.A., and Jacobson, M.I., 1983, Structures associated with the southwest margin of the ancestral Uncompahgre uplift, in Averett, W.R., ed., Northern Paradox basinUncompahgre uplift: Grand Junction Geological Society Annual Field Trip, October 1-2, 1983, Guidebook, p. 33-39.

Williams, P.L., 1964, Geology, structure, and uranium deposits of the Moab quadrangle, Colorado and Utah: U.S. Geological Survey Miscellaneous Geologic Investigations Map I-360, scale 1:250,000, 2 sheets. 
Table 1. Chemical composition of Proterozoic rocks from the northwestern part of the Uncompahgre Plateau

[Analysts: A, Leonard Shapiro, Paul Elmore, Sam Botts, and Lowell Artis; B, Ellen Daniels. Leaders (--), not determined; tr, trace; ?, uncertain]

\begin{tabular}{|c|c|c|c|c|}
\hline \multicolumn{5}{|c|}{ FELDSPATHIC GNEISS (Xfg) } \\
\hline Lab. No. and analyst & 164941-A & 164943-A & D101063-B & 164949-A \\
\hline Field No. & C-64-81b & C- $64-84$ & C-64-97 & C-64-101 \\
\hline Latitude & $38^{\circ} 57.9^{\prime}$ & $38^{\circ} 59.0^{\prime}$ & $38^{\circ} 58.9^{\prime}$ & $39^{\circ} 01.3^{\prime}$ \\
\hline Longitude & $109^{\circ} 07.6^{\prime}$ & $109^{\circ} 10.2^{\prime}$ & $109^{\circ} 10.6^{\prime}$ & $109^{\circ} 08.1^{\prime}$ \\
\hline Description & $\begin{array}{c}\text { Gray, medium grained, } \\
\text { granoblastic }\end{array}$ & $\begin{array}{l}\text { Pink, fine to medium } \\
\text { grained, lepidoblastic }\end{array}$ & $\begin{array}{l}\text { Gray, medium grained, } \\
\text { feldspar, quartz, biotite }\end{array}$ & $\begin{array}{l}\text { Gray, fine grained, } \\
\text { granoblastic, chloritic }\end{array}$ \\
\hline \multicolumn{5}{|c|}{ Major-element oxides and elements, in weight percent } \\
\hline $\mathrm{SiO}_{2}$ & 78.4 & 77.7 & 70.24 & 81.0 \\
\hline $\mathrm{Al}_{2} \mathrm{O}_{3}$ & 12.1 & 12.3 & 13.83 & 10.0 \\
\hline $\mathrm{Fe}_{2} \mathrm{O}_{3}$ & .28 & 1.2 & 1.32 & .71 \\
\hline $\mathrm{FeO}$ & .84 & .64 & 3.44 & .90 \\
\hline $\mathrm{MgO}$ & .1 & .3 & 1.34 & .5 \\
\hline $\mathrm{CaO}$ & 2.0 & 1.6 & 3.92 & .55 \\
\hline $\mathrm{Na}_{2} \mathrm{O}$ & 4.4 & 4.5 & 3.49 & 5.2 \\
\hline $\mathrm{K}_{2} \mathrm{O}$ & .45 & 0 & 1.08 & 0 \\
\hline $\mathrm{H}_{2} \mathrm{O}^{-}$ & .05 & .06 & .06 & .02 \\
\hline $\mathrm{H}_{2} \mathrm{O}^{+}$ & .55 & .68 & .78 & .78 \\
\hline $\mathrm{TiO}_{2}$ & .09 & .07 & .30 & .11 \\
\hline $\mathrm{P}_{2} \mathrm{O}_{5}$ & 0 & .07 & .11 & .02 \\
\hline $\mathrm{MnO}$ & 0 & 0 & .09 & 0 \\
\hline $\mathrm{CO}_{2}$ & .10 & .14 & .02 & .05 \\
\hline $\mathrm{Cl}$ & -- & -- & 0 & -- \\
\hline $\mathrm{F}$ & -- & -- & .06 & -- \\
\hline Subtotal & 99.36 & 99.26 & 100.08 & 99.84 \\
\hline Less 0 & $-\cdot$ & -- & .03 & -- \\
\hline Total & 99.36 & 99.26 & 100.05 & 99.84 \\
\hline \multicolumn{5}{|c|}{ Mode, in percent } \\
\hline$\overline{\text { Quartz }}$ & 66.4 & 67.8 & (Thin section & 53.3 \\
\hline K-feldspar & $2.1(?)$ & $\ldots$ & lost) &.. \\
\hline Plagioclase & 22.2 & 19.9 & & 34.9 \\
\hline Amphibole & .- & 7.7 & & $\operatorname{tr}$ \\
\hline Biotite & 8.3 & $\ldots$ & & .6 \\
\hline Muscovite & .. & .- & & .- \\
\hline Chlorite & -- & -- & & 7.6 \\
\hline Sphene & .- & $\operatorname{tr}$ & & .. \\
\hline Opaque grains & .6 & 1.9 & & .3 \\
\hline Other & .4 & 2.7 & & 3.3 \\
\hline Total & 100.0 & 100.0 & & 100.0 \\
\hline Number of points & 369 & 333 & & 316 \\
\hline
\end{tabular}


Table 1. Chemical composition of Proterozoic rocks from the northwestern part of the Uncompahgre Plateau-Continued

AMPHIBOLE GNEISS AND AMPHIBOLITE (Xa)

Lab. No. and analyst
Field No.
Latitude
Longitude
Description

$$
\begin{gathered}
164947-A \\
C-64-94 \\
38^{\circ} 56.6^{\prime} \\
109^{\circ} 05.2^{\prime}
\end{gathered}
$$

Dark green, fine grained, nematoblastic
$164948-A$

C-64-98

$39^{\circ} 00.2^{\prime}$

$109^{\circ} 08.0^{\prime}$

\begin{tabular}{|c|c|c|}
\hline $\mathrm{SiO}_{2}$ & 51.5 & 47.6 \\
\hline $\mathrm{Al}_{2} \mathrm{O}_{3}$ & 13.4 & 15.0 \\
\hline $\mathrm{Fe}_{2} \mathrm{O}_{3}$ & 2.6 & 3.2 \\
\hline $\mathrm{FeO}$ & 10.9 & 10.0 \\
\hline $\mathrm{MgO}$ & 5.9 & 7.7 \\
\hline $\mathrm{CaO}$ & 9.8 & 11.0 \\
\hline $\mathrm{Na}_{2} \mathrm{O}$ & 3.0 & 2.7 \\
\hline $\mathrm{K}_{2} \mathrm{O}$ & .12 & .34 \\
\hline $\mathrm{H}_{2} \mathrm{O}^{-}$ & .15 & .03 \\
\hline $\mathrm{H}_{2} \mathrm{O}^{+}$ & .95 & .93 \\
\hline $\mathrm{TiO}_{2}$ & 1.1 & .86 \\
\hline $\mathrm{P}_{2} \mathrm{O}_{5}$ & .14 & .09 \\
\hline $\mathrm{MnO}$ & .20 & .20 \\
\hline $\mathrm{CO}_{2}$ & .10 & .09 \\
\hline Total & 99.86 & 99.74 \\
\hline \multicolumn{3}{|c|}{ Mode, in percent } \\
\hline Amphibole & 48.9 & 64.6 \\
\hline Quartz & 33.5 & 25.2 \\
\hline Plagioclase & 13.5 & 6.6 \\
\hline Opaque grains & 2.2 & .7 \\
\hline Other & 1.9 & 2.9 \\
\hline Total & 100.0 & 100.0 \\
\hline Number of points & 312 & 311 \\
\hline
\end{tabular}

Dark green, fine grained, nematoblastic

Major-element oxides and elements, in weight percent 
Table 1. Chemical composition of Proterozoic rocks from the northwestern part of the Uncompahgre Plateau-Continued

\begin{tabular}{|c|c|c|c|c|}
\hline \multicolumn{5}{|c|}{ BIOTITE-MICROCLINE GNEISS (Xbm) } \\
\hline Lab. No. and analyst & 164936-A & 164938-A & $164945-\mathrm{A}$ & 164946-A \\
\hline Field No. & C-64-71 & C- $64-73$ & C-64-87 & C-64-92 \\
\hline Latitude & $38^{\circ} 56.6^{\prime}$ & $38^{\circ} 56.1^{\prime}$ & $38^{\circ} 59.3^{\prime}$ & $38^{\circ} 56.6^{\prime}$ \\
\hline Longitude & $109^{\circ} 07.5^{\prime}$ & $109^{\circ} 03.9^{\prime}$ & $109^{\circ} 01.3^{\prime}$ & $109^{\circ} 04.78^{\prime}$ \\
\hline Description & $\begin{array}{l}\text { Pink, fine grained, } \\
\text { granoblastic, } \\
\text { migmatitic }\end{array}$ & $\begin{array}{l}\text { Fine to medium } \\
\text { grained, granoblastic }\end{array}$ & $\begin{array}{l}\text { Gray, fine to medium } \\
\text { grained, lepidoblastic }\end{array}$ & $\begin{array}{c}\text { Pink, fine grained, } \\
\text { lepidoblastic, } \\
\text { migmatitic }\end{array}$ \\
\hline \multicolumn{5}{|c|}{ Major-element oxides and elements, in weight percent } \\
\hline $\mathrm{SiO}_{2}$ & 69.1 & 73.1 & 73.7 & 73.1 \\
\hline $\mathrm{Al}_{2} \mathrm{O}_{3}$ & 14.8 & 12.7 & 12.3 & 12.7 \\
\hline $\mathrm{Fe}_{2} \mathrm{O}_{3}$ & 1.1 & 2.6 & .78 & 1.4 \\
\hline $\mathrm{FeO}$ & 3.2 & 2.1 & 3.2 & 2.7 \\
\hline $\mathrm{MgO}$ & .8 & 1.1 & 1.2 & .3 \\
\hline $\mathrm{CaO}$ & .85 & 1.2 & 1.4 & .95 \\
\hline $\mathrm{Na}_{2} \mathrm{O}$ & 2.9 & 2.0 & 2.5 & 2.6 \\
\hline $\mathrm{K}_{2} \mathrm{O}$ & 5.1 & 2.5 & 2.8 & 4.6 \\
\hline $\mathrm{H}_{2} \mathrm{O}^{-}$ & .09 & .14 & .19 & .08 \\
\hline $\mathrm{H}_{2} \mathrm{O}^{+}$ & 1.1 & 1.6 & 1.0 & .83 \\
\hline $\mathrm{TiO}_{2}$ & .47 & .65 & .62 & .40 \\
\hline $\mathrm{P}_{2} \mathrm{O}_{5}$ & .11 & .09 & .12 & .04 \\
\hline $\mathrm{MnO}$ & .13 & .14 & .02 & .10 \\
\hline $\mathrm{CO}_{2}$ & .09 & .08 & .08 & .09 \\
\hline Total & 99.84 & 100.00 & 99.91 & 99.89 \\
\hline \multicolumn{5}{|c|}{ Mode, in percent } \\
\hline Quartz & 31.0 & 46.2 & 39.9 & 41.4 \\
\hline K-feldspar & 26.1 & 10.5 & 11.8 & 26.7 \\
\hline Plagioclase & 13.5 & 12.0 & 17.3 & 9.3 \\
\hline Biotite & 22.3 & 18.3 & 28.6 & 15.8 \\
\hline Muscovite & 5.2 & 6.4 & 1.5 & 2.8 \\
\hline Opaque grains & $\operatorname{tr}$ & .9 & $\operatorname{tr}$ & $\operatorname{tr}$ \\
\hline Sphene(?) & -. & .- & .. & 1.5 \\
\hline Other & 1.9 & 5.7 & .9 & 2.5 \\
\hline Total & 100.0 & 100.0 & 100.0 & 100.0 \\
\hline Number of points & 308 & 333 & 329 & 323 \\
\hline
\end{tabular}


Table 1. Chemical composition of Proterozoic rocks from the northwestern part of the Uncompahgre Plateau-Continued

\begin{tabular}{|c|c|c|c|c|c|}
\hline \multicolumn{3}{|c|}{ GNEISSIC GRANODIORITE (Xgg) } & \multicolumn{3}{|c|}{ METAGABBRO (YXd) } \\
\hline Lab. No. and analyst & 164937-B & 164939-B & & D101064-B & D101065-B \\
\hline Field No. & C-64-72 & C-64-76a & & C-64-102 & C-64-103 \\
\hline Latitude & $38^{\circ} 56.7^{\prime}$ & $38^{\circ} 55.7^{\prime}$ & & $39^{\circ} 02.4^{\prime}$ & $39^{\circ} 00.7^{\prime}$ \\
\hline Longitude & $109^{\circ} 04.4^{\prime}$ & $109^{\circ} 03.3^{\prime}$ & & $109^{\circ} 07.4^{\prime}$ & $109^{\circ} 05.9^{\prime}$ \\
\hline Description & $\begin{array}{c}\text { Gray, medium } \\
\text { grained, } \\
\text { lepidoblastic }\end{array}$ & $\begin{array}{l}\text { Gray, medium to } \\
\text { coarse grained, } \\
\text { lepidoblastic }\end{array}$ & $\begin{array}{r}\text { Gr } \\
\text { medi } \\
\text { gra }\end{array}$ & $\begin{array}{l}\text { Jray, fine to } \\
\text { dium grained, } \\
\text { granoblastic }\end{array}$ & $\begin{array}{c}\text { Dark gray, } \\
\text { coarse grained, } \\
\text { granoblastic }\end{array}$ \\
\hline \multicolumn{6}{|c|}{ Major-element oxides and elements, in weight percent } \\
\hline $\mathrm{SiO}_{2}$ & 71.9 & 58.9 & & 49.79 . & 51.61 \\
\hline $\mathrm{Al}_{2} \mathrm{O}_{3}$ & 14.0 & 14.5 & & 17.36 & 19.12 \\
\hline $\mathrm{Fe}_{2} \mathrm{O}_{3}$ & .77 & 1.9 & & 1.95 & 1.20 \\
\hline $\mathrm{FeO}$ & 2.3 & 4.7 & & 12.87 & 8.55 \\
\hline $\mathrm{MgO}$ & .3 & 2.0 & & 3.69 & 5.41 \\
\hline $\mathrm{CaO}$ & 1.6 & 10.3 & & 7.15 & 8.72 \\
\hline $\mathrm{Na}_{2} \mathrm{O}$ & 3.2 & 2.3 & & 3.30 & 3.23 \\
\hline $\mathrm{K}_{2} \mathrm{O}$ & 3.9 & 2.2 & & .40 & .27 \\
\hline $\mathrm{H}_{2} \mathrm{O}^{-}$ & .09 & .22 & & .13 & .13 \\
\hline $\mathrm{H}_{2} \mathrm{O}^{+}$ & .91 & 1.4 & & .57 & .40 \\
\hline $\mathrm{TiO}_{2}$ & .73 & .69 & & 1.85 & 1.13 \\
\hline $\mathrm{P}_{2} \mathrm{O}_{5}$ & .05 & .18 & & .54 & .02 \\
\hline $\mathrm{MnO}$ & .15 & .11 & & .29 & .18 \\
\hline $\mathrm{CO}_{2}$ & .14 & .14 & & .26 & .10 \\
\hline $\mathrm{Cl}^{2}$ & -. & .- & & .01 & 0 \\
\hline $\mathrm{F}$ & -- & $-\cdot$ & & .04 & .01 \\
\hline Subtotal & 100.04 & 99.54 & & 100.20 & 100.08 \\
\hline Less 0 & -- & -- & & 0.02 & 0.00 \\
\hline Total & 100.04 & 99.54 & & 100.18 & 100.08 \\
\hline \multicolumn{6}{|c|}{ Mode, in percent } \\
\hline Quartz & 35.8 & 28.6 & Plagioclase & 57.0 & 58.8 \\
\hline Plagioclase & 17.9 & 21.3 & Amphibole & 29.6 & 32.4 \\
\hline K-feldspar & 29.2 & 7.2 & K-feldspar & 2.3 & 2.5 \\
\hline Biotite & 12.9 & 41.5 & Zircon & .7 & $\operatorname{tr}$ \\
\hline Muscovite & 1.0 & $\operatorname{tr}$ & Quartz & 1.7 & .. \\
\hline Opaque grains & .2 & $\operatorname{tr}$ & Opaque grains & ins 6.0 & 3.8 \\
\hline Other & 3.5 & .9 & Other & 2.7 & 2.5 \\
\hline Total & 100.0 & 100.0 & & 100.0 & 100.0 \\
\hline Number of points & 411 & 350 & & 301 & 322 \\
\hline
\end{tabular}


Table 1. Chemical composition of Proterozoic rocks from the northwestern part of the Uncompahgre Plateau-Continued

\begin{tabular}{|c|c|c|c|}
\hline \multicolumn{3}{|c|}{ METAPYROXENITE (YXp) } & VERNAL MESA(?) QUARTZ MONZONITE (Yv) \\
\hline Lab. No. and analyst & $164950-\mathrm{A}$ & $164951-A$ & 164944-A \\
\hline Field No. & C-64-104 & C-64-105 & C-64-85 \\
\hline Latitude & $39^{\circ} 02.5^{\prime}$ & $39^{\circ} 02.5^{\prime}$ & $38^{\circ} 54.7^{\prime}$ \\
\hline Longitude & $109^{\circ} 07.4^{\prime}$ & $109^{\circ} 07.5^{\prime}$ & $109^{\circ} 03.9^{\prime}$ \\
\hline Description & $\begin{array}{c}\text { Dark gray, medium } \\
\text { to coarse grained, } \\
\text { granoblastic }\end{array}$ & $\begin{array}{c}\text { Dark gray, medium } \\
\text { to coarse grained, } \\
\text { granoblastic, } \\
\text { hematitic }\end{array}$ & $\begin{array}{l}\text { Pink to gray, } \\
\text { coarse grained, } \\
\text { porphyritic, } \\
\text { feldspathic, biotitic }\end{array}$ \\
\hline \multicolumn{4}{|c|}{ Major-element oxides and elements, in weight percent } \\
\hline $\mathrm{SiO}_{2}$ & 50.4 & 51.4 & 60.4 \\
\hline $\mathrm{Al}_{2} \mathrm{O}_{3}$ & 9.7 & 2.1 & 16.6 \\
\hline $\mathrm{Fe}_{2} \mathrm{O}_{3}$ & 1.8 & 5.0 & 3.6 \\
\hline $\mathrm{FeO}$ & 8.7 & 3.7 & 2.1 \\
\hline $\mathrm{MgO}$ & 12.2 & 19.4 & 2.4 \\
\hline $\mathrm{CaO}$ & 11.7 & 14.3 & 4.0 \\
\hline $\mathrm{Na}_{2} \mathrm{O}$ & 1.7 & .62 & 3.7 \\
\hline $\mathrm{K}_{2} \mathrm{O}$ & .80 & .14 & 4.6 \\
\hline $\mathrm{H}_{2} \mathrm{O}^{-}$ & .13 & .27 & .17 \\
\hline $\mathrm{H}_{2}^{2} \mathrm{O}^{+}$ & 1.1 & 1.1 & .93 \\
\hline $\mathrm{TiO}_{2}$ & .91 & .22 & .95 \\
\hline $\mathrm{P}_{2} \mathrm{O}_{5}$ & .18 & .04 & .43 \\
\hline $\mathrm{MnO}$ & .20 & .16 & .08 \\
\hline $\mathrm{CO}_{2}$ & .28 & .86 & .05 \\
\hline \multirow[t]{2}{*}{ Total } & 99.80 & 99.31 & 100.01 \\
\hline & & Mode, in percent ${ }^{1}$ & . \\
\hline Amphibole & 87.6 & 82.7 & Amphibole \\
\hline Plagioclase & 8.5 & .5 & Plagioclase \\
\hline Biotite & -- & 2.8 & Biotite \\
\hline Opaque grains & 1.2 & 10.4 & Quartz \\
\hline \multirow[t]{4}{*}{ Other } & 2.7 & 3.6 & K-feldspar \\
\hline & & & Sphene \\
\hline & & & Epidote \\
\hline & & & Other grains \\
\hline Total & 100.0 & 100.0 & 100.0 \\
\hline Number of points & 333 & 362 & \\
\hline
\end{tabular}

1Unit Yv: thin section for C-64-85 lost; values are average modes determined by counts of more than 300 points for samples C-62-19, C-62-20, C-63-72, and C-63-73. 